Special issue of the 2nd International Conference on Computational and Experimental Science and Engineering (ICCESEN 2015)

\title{
Identification of Structural and Spectral Features of 2-Amino 4-Chlorobenzoic Acid and 4-Amino 2-Chlorobenzoic Acid: A Comparative Experimental and DFT Study
}

\author{
N. KAYA KinAYTÜRK ${ }^{a}$ AND H. OtURAK ${ }^{b *}$ \\ ${ }^{a}$ Süleyman Demirel University, Experimental and Observational Research and Application Centre, Isparta, Turkey \\ ${ }^{2}$ Süleyman Demirel University, Physics Department, Isparta, Turkey
}

\begin{abstract}
The structure and spectroscopic data of the molecules in the ground state were calculated using density functional theory employing B3LYP $/ 6-311++\mathrm{G}(\mathrm{d}, \mathrm{p})$ basis set. The dipol moment, linear polarizability and first hyperpolarizability values were also computed using the same basis set. A study on the electronic properties, such as HOMO-LUMO energies, were performed by time-dependent density functional theory approach. A detailed description of spectroscopic behaviour of compounds was given based on the comparison of experimental data and theoretical computations.
\end{abstract}

DOI: 10.12693 /APhysPolA.130.276

PACS/topics: 31.15.E, 33.20.Lg, 33.20.Ea

\section{Introduction}

The molecular prototype of an aromatic carboxylic acid is benzoic acid (BA). It is the simplest aromatic carboxylic acid, and it is also one of the most important acids in chemistry [1]. Derivatives of benzoic acid have been the subject of investigation for many reasons. Derivative of benzoic acid is an essential component of the vitamin complex [2]. 2-Aminobenzoic acid is known as vitamin $\mathrm{L}$, whereas 4-Aminobenzoic acid is known as vitamin $\mathrm{B}$ and bacterial vitamin $\mathrm{H}$. Vitamin B complex is a group of water-soluble substances including possible 4-Aminobenzoic acid, which is known as antibacterial agent [3]. Vitamin B complex is used in miticides, contrast media in urology, cholecystographic examinations and in the manufacture of pharmaceuticals $[4,5]$. Therefore, $\mathrm{BA}$ and derivatives have been the subject of several studies the last three decades.

Experimental and theoretical quantum chemical studies of benzoic acid and of the substituted benzoic acids have been carried out by various researches. The geometric parameters and vibrational wavenumbers of benzoic acid have been recorded in [1]. The crystal structure of 2-Amino-4-Chlorobenzoic acid (2A4ClBA) [6] and 4Amino-2-Chlorobenzoic acid (4A2ClBA) [7] were published. A detailed structural analysis of 2-Amino-5Chlorobenzoic acid was carried out by Karabacak and Çınar [8]. Samsonowicz et al. have recorded the effect of amino group substituted at 2-, 3-, 4-position of benzoic acid [3]. Sundaragenasan et al. [2, 4, 9, 10] have recorded the FT-IR and FT-Raman spectra of 2-Amino4,5-difluorobenzoic acid, 5-Amino-2-Chlorobenzoic acid, 5-Amino-2-nitrobenzoicacid and 2-Chlorobenzoic acid.

\footnotetext{
* corresponding author; e-mail: haliloturak@sdu.edu.tr
}

The aim of this paper was to determine the geometry and theoretical spectroscopic (FT-IR, FT-Raman, ${ }^{1} \mathrm{H}$ and ${ }^{13} \mathrm{C}-\mathrm{NMR}$, UV-Vis) structures of $2 \mathrm{~A} 4 \mathrm{ClBA}$ and $4 \mathrm{~A} 2 \mathrm{ClBA}$ and to compare them with experimental data. In addition, HOMO and LUMO energies of title molecules are presented.

\section{Experimental details}

The compounds of $2 \mathrm{~A} 4 \mathrm{ClBA}$ and $4 \mathrm{~A} 2 \mathrm{ClBA}$ in solid form were purchased from Sigma-Aldrich chemical company (U.S.A.) with a stated purity of greater than $98 \%$, and were used as such without further purification. The FT-IR spectrum was recorded using KBr pellets on a Perkin Elmer Spectrum BX FTIR spectrophotometer in the region of $4000-400 \mathrm{~cm}^{-1}$. The FT-Raman spectrum was obtained on a DXR-Raman microscope in the region of $3500-12 \mathrm{~cm}^{-1}$. The ${ }^{1} \mathrm{H}$ and ${ }^{13} \mathrm{C}$ NMR were taken in DMSO solutions on a Bruker Ultrashield 400 Plus NMR spectrometer. Proton and carbon signals were referenced to TMS. UV-Visible analyses were carried out with a Perkin Elmer Lambda 20 Spectrophotometer. All spectra were measured at room temperature.

\section{Computational details}

Gaussian 09 [11] software package was used for the theoretical calculations. The quantum chemical calculations were performed applying the density functional theory (DFT) method, with the B3LYP functional and the $6-311 \mathrm{G}++(\mathrm{d}, \mathrm{p})$ basis set. Since B3LYP vibrational wavenumbers are known to be higher than the experimental wavenumbers, as a result of the neglected anharmonicity effects [12], they were scaled down by a uniform scaling factor of 0.983 for wavenumbers up to $1700 \mathrm{~cm}^{-1}$ and of 0.958 for wavenumbers greater than $1700 \mathrm{~cm}^{-1}$ [13]. The scaled wavenumbers, in general, 
show good agreement with experimental ones. The geometry optimizations were followed by frequency calculations using the same basis set. Also, the same basis set and functional was used for the ${ }^{1} \mathrm{H}$ and ${ }^{13} \mathrm{C}$ NMR shielding constants calculations by applying the GIAO (gauge-including atomic orbital) method. UV-Vis spectra and electronic properties were determined by timedependent DFT (TD-DFT). The results were visualized using Gauss View program [14]. Total energy distribution, corresponding to the observed frequencies, was calculated using VEDA 4 program [15].

\section{Results and discussion}

\subsection{Molecular geometry}

The optimized molecular structures of $2 \mathrm{~A} 4 \mathrm{ClBA}$ and 4A2ClBA, calculated using DFT theory at B3LYP $/ 6$ $311++\mathrm{G}(\mathrm{d}, \mathrm{p})$ level are shown in Fig. 1a and b. Experimental crystal geometry for the title compounds has been reported by Farag et al. [6] and Khan [7]. The geometrical parameters, such as bond length, bond angle and dihedral angles, are compared with the x-ray data of title compounds, shown in Table I. The optimized and experimental crystal structure shows significant degree of agreement.

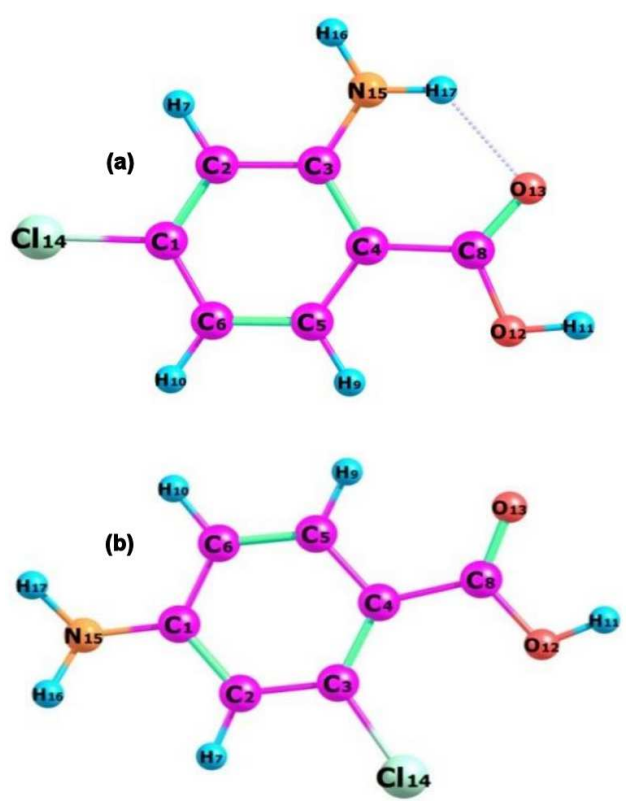

Fig. 1. The theoretical geometric structure of (a) $2 \mathrm{~A} 4 \mathrm{ClBA}$ and (b) $4 \mathrm{~A} 2 \mathrm{ClBA}$.

\subsection{Conformer analysis}

The structure of the molecules, with numbering scheme for the atoms and torsion angles, is presented in Fig. 1a and $b$. We have performed the potential energy surface analysis on the rotations $\theta$ (C5-C4-C8-O12) and $\phi$ (C4-C8-O12-H11) torsion angles, scanning from $-180^{\circ}$ to $180^{\circ}$ in steps of $10^{\circ}$. Potential energy surface scan studies have been carried out by DFT calculations using
6-31G(d) basis set (Fig. 2a and b) for both molecules. Basis set 6-31G(d) was used because there were some computational errors in high sets. The most stable conformers were obtained with the energy of -935.7790 a.u. $(-25463.85 \mathrm{eV})$, and with the torsion angles of $180^{\circ}$ $(\omega)$ and $180^{\circ}(\varphi)$ for $2 \mathrm{~A} 4 \mathrm{ClBA}$ and -935.7650 a.u. $(-25463.47 \mathrm{eV})$, and with the torsion angles of $180^{\circ}$ $(\omega)$ and $180^{\circ}(\varphi)$ for $4 \mathrm{~A} 2 \mathrm{ClBA}$, respectively. The computational processes were then followed by the geometry optimization, carried out using DFT/B3LYP/6$311++\mathrm{G}(\mathrm{d}, \mathrm{p})$ level of theory. The energy of the most stable conformer and dihedral angles $(\theta, \phi)$ were found to be -935.9545 a.u. (25468.63 eV) and -935.9409 a.u. $(25468.26 \mathrm{eV})$ and $0.8906^{\circ},-179.80^{\circ}$ and $-179.02^{\circ}$, $179.93^{\circ}$, respectively.
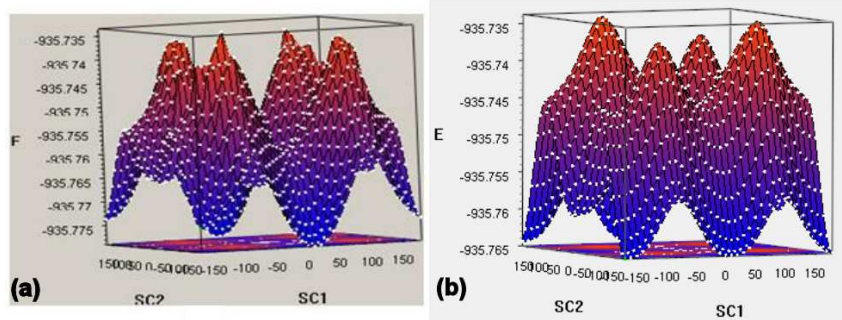

Fig. 2. The potential energy surface scan for (a) $2 \mathrm{~A} 4 \mathrm{ClBA}$ and (b) $4 \mathrm{~A} 2 \mathrm{ClBA}$.

\subsection{Vibration analysis}

\subsection{1. $C-H$ vibrations}

The characteristic $\mathrm{C}-\mathrm{H}$ bands in aromatic compounds are investigated in three distinctive regions [16]. The asymmetric and symmetric $\mathrm{C}-\mathrm{H}$ stretching bands appear in the $3100-3000 \mathrm{~cm}^{-1}$ range, the in-plane $\mathrm{C}-\mathrm{H}$ stretching bands in the $1275-1000 \mathrm{~cm}^{-1}$ and the outof-plane $\mathrm{C}-\mathrm{H}$ stretching bands in the $900-650 \mathrm{~cm}^{-1}$ range $[16,17]$. As a result of the theoretical calculation of vibrational frequencies of $2 \mathrm{~A} 4 \mathrm{ClBA}$ molecule, the $3115 \mathrm{~cm}^{-1}\left[\nu_{\mathrm{CH}}(97)\right], 3131 \mathrm{~cm}^{-1}\left[\nu_{\mathrm{CH}}(96)\right], 3145 \mathrm{~cm}^{-1}$ $\left[\nu_{\mathrm{CH}}(93)\right]$ range was assigned to $\mathrm{C}-\mathrm{H}$ stretching bands, the $1256 \mathrm{~cm}^{-1}\left[\delta_{\mathrm{HCC}}(66)\right]$ to the in-plane $\mathrm{C}-\mathrm{H}$ stretching bands and $754 \mathrm{~cm}^{-1}\left[\tau_{\mathrm{HCCC}}(70)\right]$ and $823 \mathrm{~cm}^{-1}$ $\left[\tau_{\mathrm{HCCC}}(50)\right]$ to the out-of-plane $\mathrm{C}-\mathrm{H}$ stretching bands. Regarding the experimental results, while the $\mathrm{C}-\mathrm{H}$ stretching bands appeared in the 2945-3000-3057 $\mathrm{cm}^{-1}$ range in the IR spectrum, in-plane and out-of-plane $\mathrm{C}$ $\mathrm{H}$ stretching bands were observed in the 1315 and 760 $849 \mathrm{~cm}^{-1}$ ranges, respectively. Similarly, the corresponding bands of $4 \mathrm{~A} 2 \mathrm{ClBA}$ molecule were theoretically assigned to $3116 \mathrm{~cm}^{-1}\left[\nu_{\mathrm{CH}}(100)\right], 3134 \mathrm{~cm}^{-1}\left[\nu_{\mathrm{CH}}(97)\right]$, $3151 \mathrm{~cm}^{-1}\left[\nu_{\mathrm{CH}}(94)\right], 1112 \mathrm{~cm}^{-1}\left[\delta_{\mathrm{HCC}}(66)\right], 1219 \mathrm{~cm}^{-1}$ $\left[\delta_{\mathrm{HCC}}(47)\right]$, and $805 \mathrm{~cm}^{-1}\left[\tau_{\mathrm{HCCN}}(62)\right], 821 \mathrm{~cm}^{-1}$ $\left[\tau_{\mathrm{HCCN}}(71)\right], 949 \mathrm{~cm}^{-1}\left[\tau_{\mathrm{HCCC}}(79)\right]$, respectively. In the experimental IR spectrum, $\mathrm{C}-\mathrm{H}$ stretching bands, in-plane stretching bands and out-of-plane stretching bands were observed in the 2808-2865-2987 $\mathrm{cm}^{-1}, 1137-$ $1244 \mathrm{~cm}^{-1}$ and $789-847-965 \mathrm{~cm}^{-1}$ ranges, respectively. 


\subsection{2. $\mathrm{C}-\mathrm{NH}_{2}$ vibrations}

The scaled $-\mathrm{NH}_{2}$ symmetric and asymmetric stretches in the range of $3529-3695 \mathrm{~cm}^{-1}$ are in agreement with experimental symmetric and asymmetric stretching at 3338 and $3210 \mathrm{~cm}^{-1}$ for 4A2ClBA. The calculated $-\mathrm{NH}_{2}$ scissoring vibrations at $1577 \mathrm{~cm}^{-1}\left[\delta_{\mathrm{HNH}}(56)\right]$ and $1594 \mathrm{~cm}^{-1}\left[\delta_{\mathrm{HNH}}(67)\right]$ for title molecules is in excellent agreement with expected characteristic value, $1620 \mathrm{~cm}^{-1}$. This is also in excellent agreement with the recorded medium strong band in FT-IR at 1585 and $1597 \mathrm{~cm}^{-1}$ for $2 \mathrm{~A} 4 \mathrm{ClBA}$ and $4 \mathrm{~A} 2 \mathrm{ClBA}$, respectively. The $\mathrm{C}-\mathrm{NH}_{2}$ out of plane and in plane bending vibrations are at $191 \mathrm{~cm}^{-1}\left[\tau_{\mathrm{HNCC}}(20)\right], 388 \mathrm{~cm}^{-1}$ $\left[\delta_{\mathrm{NCC}}(42)\right]$, for $2 \mathrm{~A} 4 \mathrm{ClBA}$ and $401 \mathrm{~cm}^{-1}\left[\tau_{\mathrm{HNCC}}(96)\right]$, $271 \mathrm{~cm}^{-1}\left[\delta_{\mathrm{NCC}}(20)\right]$, for $4 \mathrm{~A} 2 \mathrm{ClBA}$, respectively.

\subsection{3. - $\mathrm{COOH}$ group vibrations}

The vibrational bands of the $\mathrm{COOH}$ groups contain the $\mathrm{C}-\mathrm{O}, \mathrm{C}=\mathrm{O}$ and $\mathrm{O}-\mathrm{H}$ vibrational modes $[18,19] . \mathrm{C}=\mathrm{O}$ stretching band appears strongly in the region of 1870 $1540 \mathrm{~cm}^{-1}$. As a result of the theoretical calculation, $1644 \mathrm{~cm}^{-1}\left[\nu_{\mathrm{OC}}(68)\right]$, and $1683 \mathrm{~cm}^{-1}\left[\nu_{\mathrm{OC}}(81)\right]$ vibration energies were assigned to $2 \mathrm{~A} 4 \mathrm{ClBA}$ and $4 \mathrm{~A} 2 \mathrm{ClBA}$ molecules, respectively. Experimental IR spectra have revealed that this band appears at 1666 and $1670 \mathrm{~cm}^{-1}$. The stretching band of -OH hydroxyl group appears approximately at $3600 \mathrm{~cm}^{-1}$. It was calculated to be at $3626 \mathrm{~cm}^{-1}\left[\nu_{\mathrm{OH}}(100)\right]$, and $3695 \mathrm{~cm}^{-1}\left[\nu_{\mathrm{OH}}(100)\right]$ for $2 \mathrm{~A} 4 \mathrm{ClBA}$ and $4 \mathrm{~A} 2 \mathrm{ClBA}$ molecules respectively and at 3501 and $3425 \mathrm{~cm}^{-1}$ in the experimental IR spectra.

\subsection{4. $C-C$ ring vibrations}

$\mathrm{C}-\mathrm{C}$ ring stretches in aromatic compounds appear in the $1600-1400 \mathrm{~cm}^{-1}$ region $[20,21]$. In this study, according to the calculation based on DFT-B3LYP$6311++\mathrm{G}(\mathrm{d}, \mathrm{p})$ basis set, ring stretches were assigned to $1549 \mathrm{~cm}^{-1}\left[\nu_{\mathrm{CC}}(32)\right], 1502 \mathrm{~cm}^{-1}\left[\nu_{\mathrm{CC}}(43)\right], 1328 \mathrm{~cm}^{-1}$ $\left[\nu_{\mathrm{CC}}(21)\right], 1298 \mathrm{~cm}^{-1}\left[\nu_{\mathrm{CC}}(33)\right], 1246 \mathrm{~cm}^{-1}\left[\nu_{\mathrm{CC}}(24)\right]$, $1071 \mathrm{~cm}^{-1}\left[\nu_{\mathrm{CC}}(35)\right], 1016 \mathrm{~cm}^{-1}\left[\nu_{\mathrm{CC}}(22)\right]$ for $2 \mathrm{~A} 4 \mathrm{ClBA}$ molecule and $1572 \mathrm{~cm}^{-1}\left[\nu_{\mathrm{CC}}(41)\right], 1519 \mathrm{~cm}^{-1}\left[\nu_{\mathrm{CC}}(59)\right]$, $1395 \mathrm{~cm}^{-1}\left[\nu_{\mathrm{CC}}(43)\right], 1285 \mathrm{~cm}^{-1}\left[\nu_{\mathrm{CC}}(38)\right], 1274 \mathrm{~cm}^{-1}$ $\left[\nu_{\mathrm{CC}}(47)\right], 879 \mathrm{~cm}^{-1}\left[\nu_{\mathrm{CC}}(63)\right]$ for $4 \mathrm{~A} 2 \mathrm{ClBA}$ molecule. The 2A4ClBA molecule appeared at 1585, 1550, 1344, $1249,1097 \mathrm{~cm}^{-1}$ in the IR spectrum and 1553, 1333, 1243, 1101, $731 \mathrm{~cm}^{-1}$ in the Raman spectrum. The 4A2ClBA molecule was observed at 1597, 1500, $1405,1286,911 \mathrm{~cm}^{-1}$ in the IR spectrum and at 1598 , 1460, 1321, $913 \mathrm{~cm}^{-1}$ in the Raman spectrum. Inplane and out-of-plane $\mathrm{C}-\mathrm{C}$ stretches are a characteristic region for ring vibrations [22]. These vibrations frequently overlap with $\mathrm{C}-\mathrm{O}-\mathrm{C}, \mathrm{O}-\mathrm{C}-\mathrm{C}$ vibrations. In the present study, in-plane and out-of-plane ring stretches, which were observed at the 208, 301 and $498 \mathrm{~cm}^{-1}$ for 2A4ClBA molecule have overlapped with $\mathrm{O}-\mathrm{C}-\mathrm{C}$ stretches. The same was observed for the 4A2ClBA molecule. The comparison of data obtained for both molecules reveals that $\mathrm{C}-\mathrm{C}$ vibration bands of $4 \mathrm{~A} 2 \mathrm{ClBA}$ are shifted to high frequency region.

\subsection{5. $C-C l$ Vibrations}

When $\mathrm{C}-\mathrm{Cl}$ stretching, in-plane and out-of-plane bending vibrations were assigned, they were compared with those of similar molecules as 2-Chlorobenzoic acid [10], p-Chlorobenzoic acid [21], 5-Amino-2Chlorobenzoic acid [9] and 2-Amino-5-Chlorobenzoic acid [8]. Shurvell [16] and Stuart [23] have assigned C-X group $(\mathrm{X}=\mathrm{Cl}, \mathrm{Br}, \mathrm{I})$ stretching vibrations to the 800 $550 \mathrm{~cm}^{-1}$ range. On the other hand, Mooney [24, 25] has assigned them to the $1129-480 \mathrm{~cm}^{-1}$ region. In the current study, these stretching vibrations were calculated to be $356 \mathrm{~cm}^{-1}\left[\nu_{\mathrm{ClC}}(11)\right], 498 \mathrm{~cm}^{-1}\left[\nu_{\mathrm{ClC}}(24)\right]$, $691 \mathrm{~cm}^{-1}\left[\nu_{\mathrm{ClC}}(12)\right], 924 \mathrm{~cm}^{-1}\left[\nu_{\mathrm{ClC}}(17)\right]$ for $2 \mathrm{~A} 4 \mathrm{ClBA}$, and $316 \mathrm{~cm}^{-1}\left[\nu_{\mathrm{ClC}}(12)\right], 401 \mathrm{~cm}^{-1}\left[\nu_{\mathrm{ClC}}(32)\right], 673 \mathrm{~cm}^{-1}$ $\left[\nu_{\mathrm{ClC}}(10)\right], 879 \mathrm{~cm}^{-1}\left[\nu_{\mathrm{ClC}}(19)\right]$ for 4A2ClBA. While $\mathrm{C}-\mathrm{Cl}$ in-plane stretching vibrations for $2 \mathrm{~A} 4 \mathrm{ClBA}$ were calculated to be at $194\left[\delta_{\mathrm{ClCC}}(34)\right]$, and $307 \mathrm{~cm}^{-1}$ $\left[\delta_{\mathrm{ClCC}}(11)\right]$, they were observed at 208 and $301 \mathrm{~cm}^{-1}$ in the Raman spectrum. Vibrations calculated to be at $440 \mathrm{~cm}^{-1}\left[\tau_{\mathrm{ClCCC}}(15)\right], 600 \mathrm{~cm}^{-1}\left[\tau_{\mathrm{ClCCC}}(23)\right]$ and $171 \mathrm{~cm}^{-1}\left[\tau_{\mathrm{ClCCC}}(39)\right], 520 \mathrm{~cm}^{-1}\left[\tau_{\mathrm{ClCCC}}(26)\right]$ for these molecules were assigned as out-of-plane $\mathrm{C}$-Cl stretches. The theoretical data, related literature and experimental data seem to be overlapping.
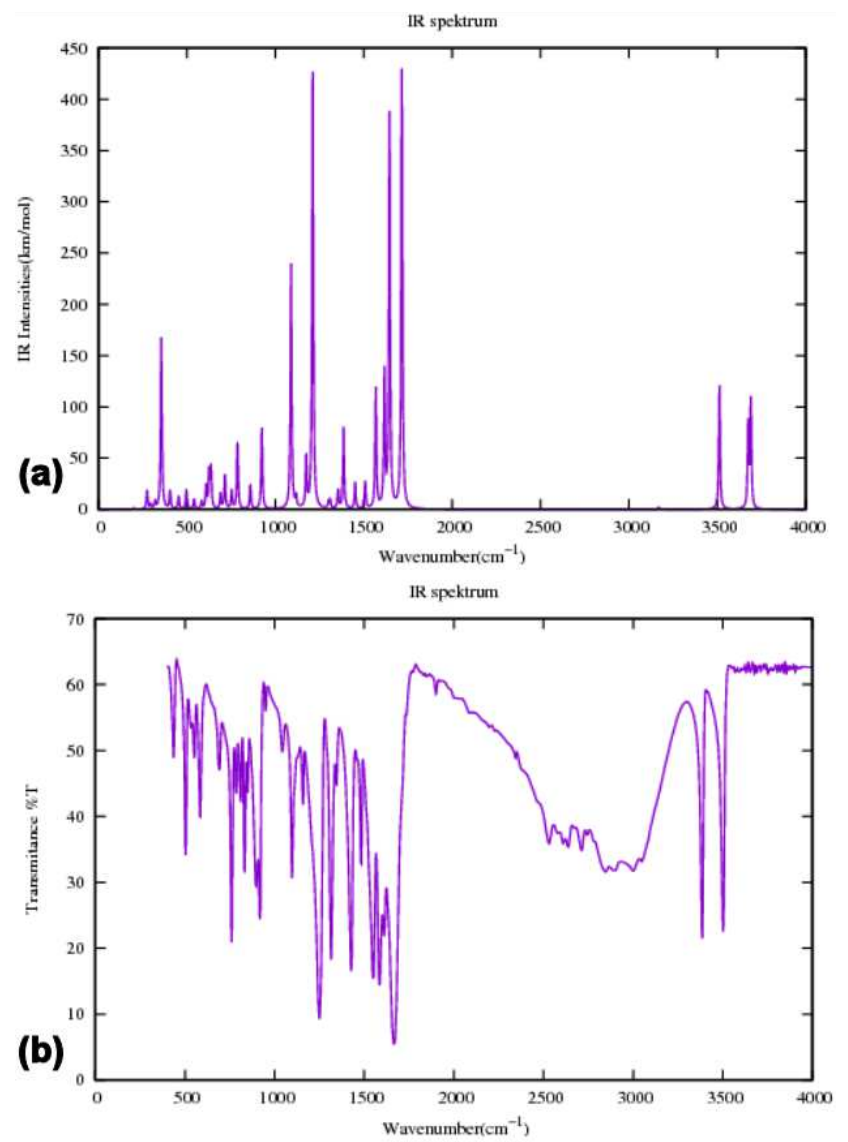

Fig. 3. The calculated (a) and experimental (b) infrared spectra of $2 \mathrm{~A} 4 \mathrm{ClBA}$. 
Optimized parameters for 2A4ClBA and 4A2ClBA (bond length, bond angles and dihedral angles).

TABLE I

\begin{tabular}{|c|c|c|c|c|c|}
\hline \multicolumn{3}{|c|}{ 2-Amino 4-Chlorobenzoic acid } & \multicolumn{3}{|c|}{ 4-Amino 2-Chlorobenzoic acid } \\
\hline Parameters & x-ray & B3LYP $6311++\mathrm{G}(\mathrm{d}, \mathrm{p})$ & Parameters & x-ray & B3LYP $6311++\mathrm{G}(\mathrm{d}, \mathrm{p})$ \\
\hline \multicolumn{6}{|c|}{ Bond lengths } \\
\hline $\mathrm{Cl14-C1}$ & 1.7425 & 1.7764 & Cl14-C3 & 1.732 & 1.7555 \\
\hline $\mathrm{O} 13-\mathrm{C} 8$ & 1.2415 & 1.2217 & $\mathrm{O} 13-\mathrm{C} 8$ & 1.226 & 1.2134 \\
\hline $\mathrm{O} 12-\mathrm{C} 8$ & 1.3197 & 1.3577 & $\mathrm{O} 12-\mathrm{C} 8$ & 1.3513 & 1.302 \\
\hline O12-H11 & 0.854 & 0.9681 & O12-H11 & 0.82 & 0.9691 \\
\hline N15-C3 & 0.3572 & 1.3598 & N15-C1 & 1.386 & 1.3801 \\
\hline N15-H16 & 0.851 & 1.0050 & N15-H16 & 0.85 & 1.008 \\
\hline N15-H17 & 0.826 & 1.0108 & N15-H17 & 0.86 & 1.008 \\
\hline C1-C6 & 1.3933 & 1.3995 & C1-C6 & 1.39 & 1.4061 \\
\hline $\mathrm{C} 1-\mathrm{C} 2$ & 1.3746 & 1.3789 & $\mathrm{C} 1-\mathrm{C} 2$ & 1.392 & 1.4019 \\
\hline C6-H10 & 0.9300 & 1.0809 & C6-H10 & 0.93 & 1.083 \\
\hline C6-C5 & 1.3816 & 1.3814 & C6-C5 & 1.37 & 1.3784 \\
\hline C5-H9 & 0.9300 & 1.0817 & C5-H9 & 0.93 & 1.083 \\
\hline $\mathrm{C} 5-\mathrm{C} 4$ & 1.4078 & 1.4066 & $\mathrm{C} 5-\mathrm{C} 4$ & 1.4087 & 1.40 \\
\hline $\mathrm{C} 4-\mathrm{C} 8$ & 1.4651 & 1.4657 & $\mathrm{C} 4-\mathrm{C} 8$ & 1.47 & 1.4853 \\
\hline C4-C3 & 1.4185 & 1.4259 & $\mathrm{C} 4-\mathrm{C} 3$ & 1.398 & 1.4093 \\
\hline $\mathrm{C} 3-\mathrm{C} 2$ & 1.4093 & 1.4129 & $\mathrm{C} 3-\mathrm{C} 2$ & 1.383 & 1.3889 \\
\hline $\mathrm{C} 2-\mathrm{H} 7$ & 0.9300 & 1.0831 & $\mathrm{C} 2-\mathrm{C} 7$ & 0.93 & 1.083 \\
\hline \multicolumn{6}{|c|}{ Bond angles $\left[{ }^{\circ}\right]$} \\
\hline C8-O12-H11 & $107.8(11)$ & 106.3513 & C8-O12-H11 & $108(2)$ & 105.91 \\
\hline C3-N15-H16 & $123.2(10)$ & 120.0303 & C1-N15-H16 & $117.7(19)$ & 117.70 \\
\hline C3-N15-H17 & $117.9(12)$ & 118.8416 & C1-N15-H17 & $117(2)$ & 118 \\
\hline Cl14-C1-C6 & $118.99(5)$ & 118.88 & Cl14-C3-C2 & $115.19(18)$ & 115.0638 \\
\hline Cl14-C1-C2 & $118.00(5)$ & 118.80 & Cl14-C3-C4 & $123.03(18)$ & 123.6495 \\
\hline C2-C3-C4 & $118.28(6)$ & 118.19 & C2-C3-C4 & $121.8(2)$ & 121.2863 \\
\hline $\mathrm{C} 3-\mathrm{C} 2-\mathrm{C} 1$ & $119.92(6)$ & 120.3082 & $\mathrm{C} 3-\mathrm{C} 2-\mathrm{C} 1$ & $120.3(2)$ & 121.0909 \\
\hline $\mathrm{C} 2-\mathrm{C} 1-\mathrm{C} 6$ & $123.01(6)$ & 122.3161 & $\mathrm{C} 2-\mathrm{C} 1-\mathrm{C} 6$ & $119.0(2)$ & 118.3761 \\
\hline N15-C3-C4 & $123.17(6)$ & 122.3078 & N15-C1-C6 & $120.8(2)$ & 121.0098 \\
\hline N15-C3-C2 & $118.55(6)$ & 119.4932 & N15-C1-C2 & $120.2(2)$ & 120.5738 \\
\hline C1-C6-C5 & $117.38(6)$ & 117.7394 & C1-C6-C5 & $120.0(2)$ & 119.8603 \\
\hline C6-C5-C4 & $121.95(7)$ & 122.2169 & C6-C5-C4 & $122.5(2)$ & 122.9419 \\
\hline C5-C4-C8 & $119.34(6)$ & 120.4702 & $\mathrm{C} 5-\mathrm{C} 4-\mathrm{C} 8$ & $118.9(2)$ & 114.9140 \\
\hline $\mathrm{C} 3-\mathrm{C} 4-\mathrm{C} 8$ & $121.20(6)$ & 120.3033 & $\mathrm{C} 3-\mathrm{C} 4-\mathrm{C} 8$ & $124.5(2)$ & 128.6415 \\
\hline C3-C4-C5 & $119.45(6)$ & 119.2248 & C3-C4-C5 & $116.5(2)$ & 116.4443 \\
\hline $\mathrm{O} 13-\mathrm{C} 8-\mathrm{C} 4$ & $123.38(7)$ & 125.8351 & O13-C8-C4 & $123.8(2)$ & 123.3375 \\
\hline O12-C8-C4 & $114.92(6)$ & 113.8652 & $\mathrm{O} 12-\mathrm{C} 8-\mathrm{C} 4$ & $114.0(2)$ & 115.5287 \\
\hline O12-C8-O13 & $121.70(7)$ & 120.2996 & O12-C8-O13 & $122.1(2)$ & 121.1337 \\
\hline C3-C2-H7 & 120.0 & 120.1017 & C3-C2-H7 & 120 & 118.9112 \\
\hline C1-C2-H7 & 120.0 & 120.3082 & C1-C2-H7 & 120 & 119.9956 \\
\hline H16-N15-H17 & $117.7(15)$ & 120.2671 & H16-N15-H17 & $112(3)$ & 114.44 \\
\hline \multicolumn{6}{|c|}{ Dihedral angles $\left[{ }^{\circ}\right]$} \\
\hline N15-C3-C2-C1 & $178.90(7)$ & 179.0249 & N15-C1-C2-C3 & $-180.0(2)$ & 177.7497 \\
\hline $\mathrm{C} 4-\mathrm{C} 3-\mathrm{C} 2-\mathrm{C} 1$ & $-1.19(11)$ & -0.17 & $\mathrm{C} 4-\mathrm{C} 3-\mathrm{C} 2-\mathrm{C} 1$ & $1.1(3)$ & 0.00306 \\
\hline $\mathrm{C} 3-\mathrm{C} 2-\mathrm{C} 1-\mathrm{C} 6$ & $0.96(12)$ & -0.0447 & $\mathrm{C} 3-\mathrm{C} 2-\mathrm{C} 1-\mathrm{C} 6$ & $-2.5(3)$ & 0.03625 \\
\hline C3-C2-C1-Cl14 & $-177.87(6)$ & -179.9959 & C1-C2-C3-Cl14 & $179.44(17)$ & 179.7966 \\
\hline $\mathrm{C} 2-\mathrm{C} 1-\mathrm{C} 4-\mathrm{C} 5$ & $-0.05(12)$ & -0.1448 & $\mathrm{C} 2-\mathrm{C} 3-\mathrm{C} 4-\mathrm{C} 5$ & $0.4(3)$ & 0.0157 \\
\hline Cl14-C1-C4-C5 & $178.77(6)$ & -179.9041 & Cl14-C3-C4-C5 & $-179.00(17)$ & -179.7597 \\
\hline $\mathrm{C} 1-\mathrm{C} 6-\mathrm{C} 5-\mathrm{C} 4$ & $-0.59(12)$ & -0.0256 & $\mathrm{C} 1-\mathrm{C} 6-\mathrm{C} 5-\mathrm{C} 4$ & $-1.0(4)$ & 0.1204 \\
\hline C6-C5-C4-C3 & $0.33(11)$ & -0.025 & C6-C5-C4-C3 & $-0.5(3)$ & -0.07835 \\
\hline $\mathrm{C} 6-\mathrm{C} 5-\mathrm{C} 4-\mathrm{C} 8$ & $-178.31(7)$ & 179.3565 & C6-C5-C4-C8 & $176.5(2)$ & 179.99 \\
\hline N15-C3-C4-C5 & $-179.53(8)$ & -178.8900 & N15-C1-C6-C5 & $179.9(2)$ & -177.7988 \\
\hline $\mathrm{C} 2-\mathrm{C} 3-\mathrm{C} 4-\mathrm{C} 5$ & $0.57(11)$ & 0.2810 & $\mathrm{C} 2-\mathrm{C} 1-\mathrm{C} 6-\mathrm{C} 5$ & $2.5(3)$ & -0.0957 \\
\hline N15-C3-C4-C8 & $-0.92(12)$ & 1.5652 & & & \\
\hline $\mathrm{C} 2-\mathrm{C} 3-\mathrm{C} 4-\mathrm{C} 8$ & $179.18(7)$ & -179.2637 & $\mathrm{C} 2-\mathrm{C} 3-\mathrm{C} 4-\mathrm{C} 8$ & $-176.4(2)$ & 179.9363 \\
\hline C5-C4-C8-O13 & $174.64(7)$ & -179.9569 & $\mathrm{C} 5-\mathrm{C} 4-\mathrm{C} 8-\mathrm{O} 13$ & $-172.3(2)$ & -179.0213 \\
\hline C3-C4-C8-O13 & $-3.97(12)$ & 0.5821 & C3-C4-C8-O13 & $4.4(4)$ & 1.05712 \\
\hline C5-C4-C8-O12 & $-5.06(11)$ & 0.8907 & C5-C4-C8-O12 & $7.8(3)$ & 0.8792 \\
\hline C3-C4-C8-O12 & $176.34(7)$ & -179.5703 & C3-C4-C8-O12 & $-175.4(2)$ & -179.0424 \\
\hline
\end{tabular}



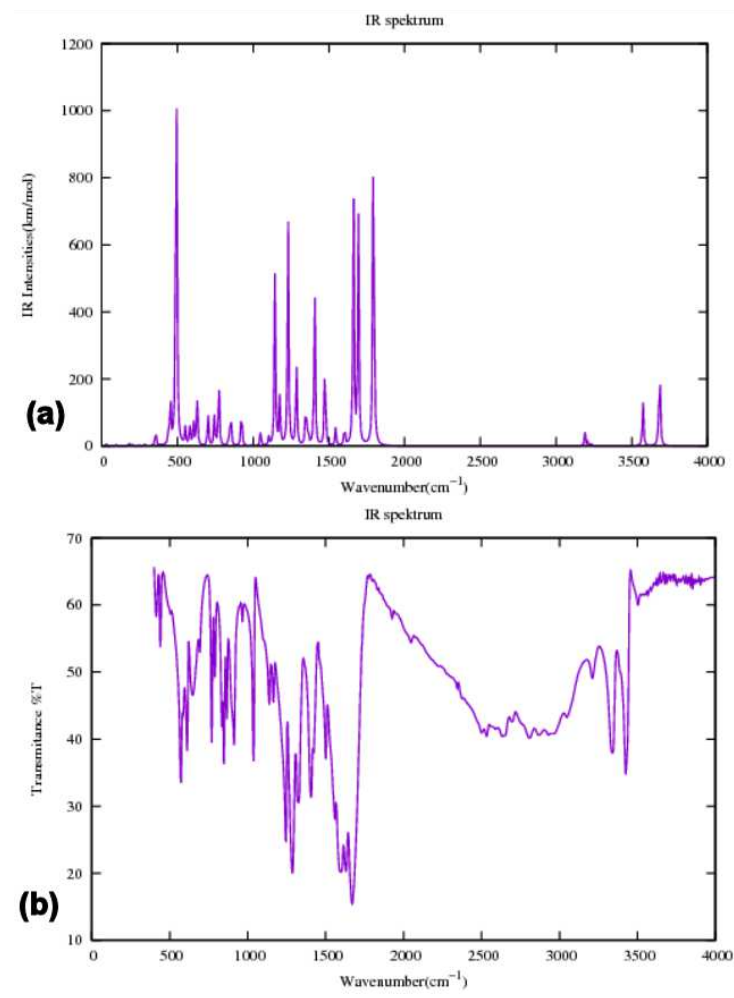

Fig. 4. The calculated (a) and experimental (b) infrared spectra of $4 \mathrm{~A} 2 \mathrm{ClBA}$.

\subsection{NMR analysis}

The ${ }^{13} \mathrm{C}$ and ${ }^{1} \mathrm{H}$ theoretical and experimental chemical shifts and the assignments of $2 \mathrm{~A} 4 \mathrm{ClBA}$ and $4 \mathrm{~A} 2 \mathrm{ClBA}$ are shown in Table II. In recent years, GIAO computational method has became efficient in predicting chemical shifts of various organic compounds [26]. In this study, the optimized structures of $2 \mathrm{~A} 4 \mathrm{ClBA}$ and $4 \mathrm{~A} 2 \mathrm{ClBA}$ are used to calculate the NMR spectra using the DFT/B3LYP

TABLE II

Experimental and theoretical ${ }^{13} \mathrm{C}$ and ${ }^{1} \mathrm{H}$ NMR isotropic chemical shifts of $2 \mathrm{~A} 4 \mathrm{ClBA}$ and $4 \mathrm{~A} 2 \mathrm{ClBA}$ with DFT (B3LYP 6-311++G(d,p)) method.

\begin{tabular}{c|c|c|c|c}
\hline \hline & \multicolumn{2}{|c|}{ B3LYP $6311++\mathrm{G}(\mathrm{d}, \mathrm{p})[\mathrm{ppm}]$} & \multicolumn{2}{|c}{ Experimental } \\
\hline ATOM & 2A4ClBA & $4 \mathrm{~A} 2 \mathrm{ClBA}$ & 2A4ClBA & $4 \mathrm{~A} 2 \mathrm{ClBA}$ \\
\hline $\mathrm{C}(1)$ & 157.81 & 157.58 & 138.32 & 153.09 \\
$\mathrm{C}(2)$ & 118.72 & 121.14 & 114.74 & 114.99 \\
$\mathrm{C}(3)$ & 159.07 & 157.21 & 152.37 & 134.83 \\
$\mathrm{C}(4)$ & 110.56 & 120.76 & 108.58 & 114.61 \\
$\mathrm{C}(5)$ & 140 & 142.45 & 133.01 & 133.80 \\
$\mathrm{C}(6)$ & 121.12 & 114.74 & 115.11 & 111.51 \\
$\mathrm{C}(8)$ & 174.6 & 168.64 & 168.90 & 166 \\
$\mathrm{H}(7)$ & 6.56 & 6.66 & 6.85 & 6.66 \\
$\mathrm{H}(9)$ & 7.99 & 8.24 & 7.72 & 7.70 \\
$\mathrm{H}(10)$ & 6.51 & 6.49 & 6.84 & 6.54 \\
$\mathrm{H}(11)$ & 5.53 & 5.40 & 6.50 & 6.01 \\
$\mathrm{H}(16)$ & 4.12 & 3.55 & 6.48 & 2.52 \\
$\mathrm{H}(17)$ & 7.7 & 3.54 & 7.7 & 2.51
\end{tabular}

method with $6-311++\mathrm{G}(\mathrm{d}, \mathrm{p})$ level using the GIAO method. The result in Table II shows that the range of ${ }^{13} \mathrm{C}$ NMR chemical shift of the typical organic molecule usually is $>100$ ppm, which ensures reliable interpretation of spectroscopic parameters $[27,28]$. In this study, ${ }^{13} \mathrm{C}$ NMR chemical shifts in the ring for the title molecules are $>100 \mathrm{ppm}$, as expected. When structures of molecules are searched the peak of carbon is seemed in downfield. A nearby electronegative atom withdraws electron density from the neighbourhood of the proton, so NMR signal of such deshielded proton will appear downfield [29]. Chemical shifts that belong to $\mathrm{C}(8)$ are the lowest of other atom in the molecules, because of the oxygen being more electronegative compared with nitrogen and chlorine. The agreement between the experimental and theoretical chemical shifts in ${ }^{13} \mathrm{C}$ and ${ }^{1} \mathrm{H}$ NMR spectra is very good.

\subsection{UV-Vis studies}

On the basis of fully optimized ground-state structure, the TD-DFT-B3LYP-6311++G(d,p) method was used to determine the low-lying excited states of $2 \mathrm{~A} 4 \mathrm{ClBA}$ and 4A2ClBA. The calculated excitation energies, oscillator strength $f$ and wavelength $\lambda$ and spectral assignments were carried out and the results were compared with measured experimental wavelengths given in Table III. According to the calculation results, three sharp electronic transitions were observed fort title molecules (335, 256, $245 \mathrm{~nm}$ for 2A4ClBA in chloroform and 294, $279,252 \mathrm{~nm}$ for $4 \mathrm{~A} 2 \mathrm{ClBA}$ in dichloromethane) in good agreement with the measured experimental data. According to Franck-Condon principle, the maximum absorption peaks correspond in an UV-Visible spectrum to a vertical excitation [30].

TABLE III

Experimental and theoretical (TD-DFT/B3LYP/6$311++\mathrm{G}(\mathrm{d}, \mathrm{p}))$ absorption wavelengths $\lambda[\mathrm{nm}]$ and excitation energies.

\begin{tabular}{l|c|c|c|c}
\hline \hline$\lambda_{\text {cal. }}$ & $\lambda_{\text {exp. }}$ & E $[\mathrm{eV}]$ & Assign. & Major contribution \\
\hline \multicolumn{5}{c}{2 A4ClBA } \\
\hline 245 & 240 & 5.0632 & $\sigma \rightarrow \pi^{*}$ & HOMO-2 $\rightarrow$ LUMO \\
256 & 253 & 4.8372 & $\pi \rightarrow \pi^{*}$ & HOMO $-1 \rightarrow$ LUMO \\
335 & 336 & 3.6954 & $\pi \rightarrow \pi^{*}$ & HOMO $\rightarrow$ LUMO \\
\hline \multicolumn{5}{c}{4 A2ClBA } \\
\hline 252 & 229 & 4.9148 & $\sigma \rightarrow \pi^{*}$ & HOMO $\rightarrow$ LUMO \\
279 & 279 & 4.4386 & $\sigma \rightarrow \pi^{*}$ & HOMO $\rightarrow$ LUMO +1 \\
294 & & 4.2132 & $\pi \rightarrow \pi^{*}$ & HOMO-2 $\rightarrow$ LUMO
\end{tabular}

In most cases the application of absorption spectroscopy to organic compounds is based on transitions for $\sigma$ or $\pi$ electrons to the $\pi^{*}$ excited state, because the energies required for these processes bring the absorption peaks into an experimentally convenient spectral region (200 to $700 \mathrm{~nm}$ ). The molar absorptivities for peaks associated with excitation of the $\sigma \rightarrow \pi^{*}$ transitions are generally low and ordinarily range from 10 to $100 \mathrm{lcm}^{-1}$; values for $\pi \rightarrow \pi^{*}$ transitions, on the other hand, normally fall in the range between 1000 and $10000 \mathrm{lcm}^{-1}$ [31]. 
The most important orbitals in molecule are the frontier molecular orbitals, called highest occupied molecular orbital (HOMO) and lowest unoccupied molecular orbital (LUMO). The calculated energy value of HOMO is -0.22892 and $-0.22640 \mathrm{eV}$, for $2 \mathrm{~A} 4 \mathrm{ClBA}$ and $4 \mathrm{~A} 2 \mathrm{ClBA}$, respectively. LUMO is -0.07376 and $-0.06734 \mathrm{eV}$, for $2 \mathrm{~A} 4 \mathrm{ClBA}$ and $4 \mathrm{~A} 2 \mathrm{ClBA}$, respectively. The value of energy separation between the HOMO and LUMO are -0.1556 and $-0.15906 \mathrm{eV}$, for $2 \mathrm{~A} 4 \mathrm{ClBA}$ and $4 \mathrm{~A} 2 \mathrm{ClBA}$, respectively.

\section{Acknowledgments}

This work was supported by a grant (Project No: 3656D2-13) from the Suleyman Demirel University Scientific Research fund.

\section{References}

[1] M. Alcolea Palafox, J.L. Nunez, M. Gil, Int. J. Quantum Chem. 89, 1 (2002).

[2] N. Sundaraganesan, S. Ilakiamani, B.D. Joshua, Spectrochim. Acta Part A 67, 287 (2007).

[3] M. Samsonowicz, T. Hrynaszkiewicz, R. Świsłocka, E. Regulska, W. Lewandowski, J. Mol. Struct. 744747, 345 (2005).

[4] N. Sundaraganesan, B.D. Joshua, K. Settu, Spectrochim. Acta Part A 66, 2 (2007).

[5] A. Syahrani, E. Ratnasari, G. Indrayanto, A.L. Wilkins, Phytochemistry 51, 615 (1999).

[6] A.M. Farag, S.G. Teoh, H. Osman, C.S. Yeap, H.-K. Fun, Acta Crystallograph. E 67, o37 (2010).

[7] M.H. Khan, I.U. Khan, M. Akkurt, Acta Crystallograph E 67, o2247 (2011).

[8] M. Karabacak, M. Çınar, Spectrochim. Acta Part A 86, 590 (2012).

[9] M. Ramalingam, N. Sundaraganesan, H. Saleem, J. Swaminathan, Spectrochim. Acta Part A 71, 23 (2008).

[10] N. Sundaraganesan, D.B. Joshua, T. Radjakoumar, Indian J. Pure App. Phys. 47, 248 (2009).

[11] M.J. Frisch, G.W. Trucks, H.B. Schlegel, G.E. Suzerain, M.A. Robb, J.R. Cheeseman Jr., J.A. Montgomery, T. Vreven, K.N. Kudin, J.C. Burant, J.M. Millam, S.S. Iyengar, J. Tomasi, V. Barone, B. Mennucci, M. Cossi, G. Scalmani, N. Rega, G.A. Petersson, H. Nakatsuji, M. Hada, M. Ehara, K. Toyota, R. Fukuda, J. Hasegawa, M. Ishida, T. Nakajima, Y. Honda, O. Kitao, H. Nakai, M. Klene, X. Li, J.E. Knox, H.P. Hratchian, J.B. Cross, V. Bakken, C. Adamo, J. Jaramillo, R. Gomperts, R.E. Stratmann, O. Yazyev, A.J. Austin, R. Cammi, C. Pomelli, J.W. Ochterski, P.Y. Ayala, K. Morokuma, G.A. Voth, P. Salvador, J.J. Dannenberg, V.G. Zakrzewski, S. Dapprich, A.D. Daniels, M.C. Strain, O. Farkas, D.K. Malick, A.D. Rabuck, K. Raghavachari, J.B. Foresman, J.V. Ortiz, Q. Cui, A.G. Baboul, S. Clifford, J. Cioslowski, B. Stefanov, G. Liu, A. Liashenko, P. Piskorz, I. Komaromi, R.L. Martin, D.J. Fox, T. Keith, M.A. Al-Laham, C.Y. Peng, A. Nanayakkara, M. Challacombe, P.M.W. Gill, B. Johnson, W. Chen, M.W. Wong, C. Gonzalez, J.A. Pople, Gaussian 09, Gaussian Inc., Pittsburgh 2003.
[12] L. Sinha, O. Prasad, M. Karabacak, H.N. Mishra, V. Narayan, A.M. Asiri, Spectrochim. Acta Part A 120, 126 (2014).

[13] N. Sundaraganesan, S. Ilakiamani, H. Saleem, P.M. Wojciechowski, D. Michalska, Spectrochim Acta Part A 61, 2995 (2005).

[14] R. Dennington, T. Keith, J. Millam, Gaussviev Version 5. s.l., Semichem Inc. Shawnee Mission, KS, (2009).

[15] MH. Jamroz, Vibrational energy distribution analysis VEDA 4, 2004.

[16] H.F. Shurvell, Spectra-Structure Correlations in the Mid- and Far- infrared in: Handbook of Vibrational Spectroscopy, Eds. J.E. Bertie, J.M. Chalmers, P.R. Griffiths, John Wiley \& Sons, 2002.

[17] B. Schrader, Infrared and Raman Spectroscopy Method and Aplication, John Wiley \& Sons, 1995.

[18] M. Karabacak, Z. Cinar, M. Kurt, S. Sudha, N. Sundaraganesan, Spectrochim. Acta Part A 85, 179 (2012).

[19] M. Ibrahim, A. Nada, D.E. Kamal, Indian J. Pure App. Phys. 43, 917 (2005).

[20] P.R. Griffiths, J.A. Haseth, Fourier Transform Infrared Spectrimetry, John Wiley \& Sons, 2007, p. 447.

[21] N. Sundaraganesan, B. Anand, C. Meganathan, B.D. Joshua, Spectrochim. Acta Part A 69, 871 (2008).

[22] V. Balachandran, S. Lalitha, S. Rajeswari, V.K. Rastogic, Spectrochimica Acta Part A 121, 575 (2014).

[23] B.H. Stuart, Infrared Spectroscopy: Fundamental and Applications. s.l., John Wiley \& Sons, 2004, s. 82.

[24] E.F. Mooney, Spectrochim. Acta 19, 877 (1963).

[25] E.F. Mooney, Spectrochim. Acta 20, 1021 (1964).

[26] A.R. Katritzky, N.G. Akhmedov, J. Doskocz, P.P. Mohapatra, C.D. Hall, A. Güven, Magn. Reson. Chem. 45, 532 (2007).

[27] D. Shoba, S. Periandi, S. Boomadevi, S. Ramalingam, E. Fereyduni, Spectrochim. Acta Part A 118, 438 (2014).

[28] M. Karabacak, Z. Cinar, M. Kurt, S. Sudha, N. Sundaraganesan, Spectrochim. Acta Part A 85, 179 (2012).

[29] D. Shoba, S. Periandi, S. Boomadevi, S. Ramalingam, E. Fereyduni, Spectrochim. Acta Part A 118, 438 (2014).

[30] L.D.S. Yadav, Organic Spectroscopy, SpringerScience + Business Media, B.V., Allahabat 2005.

[31] D.A. Skoog, D.M. West, Principles of Instrumental Analysis, Saunders College, 1980, p. 172. 